\title{
Multidrug-Resistance and Virulence-Related Properties of Diarrheagenic Escherichia Coli in Urban River: A Possible Source and Dissemination of Human Infections
}

\author{
Barbara Araújo Nogueira \\ Universidade do Estado do Rio de Janeiro https://orcid.org/0000-0002-6027-4404 \\ Julianna Giordano Botelho Olivella \\ Universidade do Estado do Rio de Janeiro \\ Bruna Ribeiro Sued-Karam \\ Universidade do Estado do Rio de Janeiro \\ Paula Marcele Afonso Pereira Ribeiro \\ Universidade do Estado do Rio de Janeiro \\ Valmir Oliveira \\ Universidade do Estado do Rio de Janeiro \\ Claudio Rocha de Souza \\ Fundação Oswaldo Cruz: Fundacao Oswaldo Cruz \\ Sergio Eduardo Longo Fracalanzza \\ Universidade Federal do Rio de Janeiro \\ Ana Claudia de Paula Rosa Ignácio \\ Universidade do Estado do Rio de Janeiro \\ Ana Luíza Mattos-Guaraldi ( $\nabla$ aguaraldi@gmail.com ) \\ Universidade do Estado do Rio de Janeiro
}

\section{Research Article}

Keywords: Escherichia coli, aquatic environment, multi-drug resistance, diarrheagenic, intestinal epithelial cell.

Posted Date: July 16th, 2021

DOI: https://doi.org/10.21203/rs.3.rs-700738/v1

License: () (1) This work is licensed under a Creative Commons Attribution 4.0 International License. Read Full License 


\section{Abstract}

The presence of multi-drug resistant (MDR) E. coli harboring virulence pathotypes in aquatic systems is a public health concern due to an increase number of cases of infections and outbreaks in industrialized and developing countries. The aim of the present study was to evaluate the microbiological quality of Joana river, located at Rio de Janeiro, by analyzing E. coli bacteria contamination and to investigate virulence properties and MDR profiles by phenotypic and genotypic methods, including bacterial interaction with Caco-2 cells. A total of $34 \mathrm{E}$. coli were identified by MALDI-TOF and $20 \mathrm{E}$. coli were characterized as MDR when submitted to antimicrobial susceptibility test. Evaluation by multiplex-PCR of MDR E. coli demonstrated the presence of virulence pathotypes: EHEC (stx1, stx2, eae genes), STEC (stx2 gene) and EIEC/STEC (stx2, iaL genes). Virulence potential was demonstrated by the ability to adhere and survive within Caco-2 cells of MDR E. coli pathotypes $(n=4)$. In conclusion, this study demonstrates the presence of diarrheagenic MDR E. coli in river water at Rio de Janeiro. The possibility of aquatic environment dissemination of antimicrobial resistance and human contamination leading to community and nosocomial infections due to virulent MDR E. coli water-borne pathogens is a matter of concern.

\section{Introduction}

Urban rivers may act as reservoir of several human pathogens, including Escherichia coli, a commensal inhabitant of the human gastrointestinal tract, considered the main indicator of water potability (Lanna et al., 2020; Guzmán et al., 2015). Although most $E$. coli strains live harmlessly in the colon, a number of pathogenic strains can cause intestinal and extraintestinal diseases, through different virulence factors, in healthy and immunocompromised individuals (Leimbach et al., 2013).

Diarrheal illnesses are a severe public health problem and a major cause of morbidity and mortality especially in Africa, Asia and Latin America due to poor living conditions, including poor environmental hygiene and sanitation. Diarrheagenic E. coli (DEC) are one of the most important of the various etiological agents of diarrhea, where strains have evolved to the acquisition, through horizontal gene transfer, of a particular set of characteristics that have persisted in the host. The DEC pathothypes are classified as: Enteropathogenic E. coli (EPEC), Enterohaemorrhagic (Shiga toxin-producing) E. coli (EHEC/STEC), Enteroaggregative E. coli (EAEC), Enterotoxigenic E. coli (ETEC) and Enteroinvasive E. coli (EIEC - based on the presence of seven virulence genes: eaeA, $s t x 1, s t x 2$, iaL, $L t, S t$ and eagg respectively. Each of these pathotypes represents a group of clones that share specific virulence factors. (Gomi et al., 2015; Gomes at al. 2016).

Several reports indicate ETEC as a major cause of diarrheal illness in poor areas of the world where they contribute to unacceptable mortality, particularly among young children (Fleckenstein; Kuhlmann, 2019); EHEC strains secret Shiga toxin (Stx) which can lead to hemolytic uremic syndrome; EPEC is an important cause of infant diarrhea and mortality worldwide; EIEC strains are involved in invasive intestinal infections and dysentery; EAEC strains cause persistent diarrhea due to a heatstable enterotoxin activity (Abe et al., 2008; Serapio-Palacios, Finlay, 2020); STEC may cause outbreaks, sporadic cases of hemorrhagic colitis and are associated with hemolytic uremic syndrome and thrombotic thrombocytopenic purpura (Beutin et al., 2004). Pathogenic E. coli strains may colonize human tissues by attaching and/or invading host cells. Clinical manifestations induced by each of these strains are associated with watery form of diarrhea or inflammatory presentation of the disease (Kalita, Hu, Torres, 2014; Wang et al., 2017; Lanna et al., 2020).

Population heterogeneity of $E$. coli has been linked to environmental changes and genome plasticity evolution of some lineages associated with human diseases due to new combinations of virulence genes and phenotypic diversity, contributing to survival, higher virulence profiles and multi-resistance dissemination (Ashbolt, 2004; Brito et al., 2008; Hartland and Leong, 2013).

Although bacterial interaction within gastrointestinal human tract is essential to maintain members of the normal microflora, it is also considered a critical phase in all diarrheal infections caused by pathogenic E. coli strains (Kalita, Hu, Torres, 2014). Epithelial cell invasion is a virulence mechanism expressed by EIEC strains leading to dysentery-like illness. Invasive properties to cultured epithelial cells have been also reported for EPEC strains (Luck et al., 2005). Therefore, understanding the occurrence of pathogenic E. coli and their ability to adhere, invade and persist in the host cell will improve the knowledge of environmental transmission media to humans and its important role in emergence outbreaks creating potential threat and becoming a public health risk (Xiong et al., 2015). However, further studies remain necessary. 
The aim of this present study was to evaluate the microbiological quality of Joana river, located at Rio de Janeiro metropolitan area, by analyzing $E$. coli bacteria contamination and to investigate virulence-related properties and multidrug-resistance profiles by phenotypic and genotypic methods, including host-cell interaction.

\section{Materials And Methods}

\section{Study area and sample collection.}

Water samples were collected from Joana River located in front of a University Hospital at Rio de Janeiro metropolitan area, Southeast Brazil, which receives water from different sources including residences, State University, rain and hospital sewage. Joana River has a total length of 3.412 meters, with 2.400 meter of tunnel, which is considered the largest urban drainage tunnel in Brazil. A flow limiter was built that allows a passage of up $7 \mathrm{~m}^{3} / \mathrm{s}$ of water from the Joana River to the Macaranã River until it flows directly into Guanabara Bay (Figure 1).

Approximately $100 \mathrm{~mL}$ of water samples were collected, stored in sterilized bags and transported to laboratory for analysis. Samples were inoculated in $100 \mathrm{~mL}$ of Brain Hearth Infusion broth - BHI (2x), incubated for $24 \mathrm{~h}$ at $37^{\circ} \mathrm{C}$, and subsequently cultivated onto MacConckey ágar $\left(24 \mathrm{~h}\right.$ at $\left.37^{\circ} \mathrm{C}\right)$, as previously described (Nogueira et al., 2015). E. coli strains were identified using Matrix Assisted Laser Desorption lonization Time-Of-Flight (MALDI-TOF) mass spectrometry. This method analyzes the profiles of bacterial macromolecule that are obtained from whole bacteria. The procedure provides a unique mass spectral fingerprint of the microorganisms, biopolymer molecules normally present in the condensed phase be converted into intact, isolated ionized molecules in the gas phase. Then, ions are separated according to their molecular weight after migration in an electric field. Each molecule detected is characterized by molecular mass, the charge, the ratio mass/charge and the relative intensity of the signal (Carbonelle et al., 2011).

\section{Antimicrobial susceptibility assays.}

Antimicrobial susceptibility testing was done by the disc diffusion method (Bauer et al., 1966), and the results were interpreted according to Clinical Laboratory Standards Institute (CLSI) guidelines (CLSI, 2019). The following antimicrobial drugs were tested: cephalosporins: cephalothin, cefazolin, cefoxitin, cefuroxime, cefotaxime, ceftriaxone, ceftazidime, cefepime; aminoglycosides: gentamicin, amikacin, kanamycin, tobramycin; ampicillin; piperacillin/taxobactam, amoxicillin/clavulanic acid, ampicillin/sulbactam; fluorquinolones: ciprofloxacin, norfloxacin; carbapenems: imipenem, ertapenem, meropenem; aztreonam; chloramphenicol; tetracycline; cotrimoxazole and colistin. Multidrug resistance was considered when strains were resistant to three or more antimicrobial agents of interest class (beta-lactams, fluorquinolones, aminoglycoside and carbapenems) (Magiorakos et al., 2012).

\section{Biofilm formation on hydrophobic polystyrene surface.}

Biofilm assays on polystyrene surfaces were performed for all E. coli strains. The optical density (OD) of the stained attached bacteria and control wells were read at $\lambda=570 \mathrm{~nm}$. The cut-off OD (ODc) was defined as the mean OD of the negative control (TSB only). Based on the ODs of the bacterial biofilms, all strains were classified into the following categories: non-adherent (-: OD $\leq \mathrm{ODc}$ ), weakly adherent (+: $\mathrm{ODc}>\mathrm{OD} \leq 2 \mathrm{x} \mathrm{ODc}$ ), moderately adherent (++: $2 x \mathrm{ODc}>\mathrm{OD} \leq 4 \mathrm{x} \mathrm{ODc})$, or strongly adherent $(+++:$ D >4x ODc). Each assay was performed in triplicate and repeated three times. S. epidermidis strain ATCC 35984 was used as a positive controll (Van Belkum et al., 2007).

\section{Biofilm formation on a hydrophilic glass surface.}

Microorganisms were inoculated in glass tubes $(15 \times 100 \mathrm{~mm})$ containing $5 \mathrm{~mL}$ of TSB medium and incubated at $37^{\circ} \mathrm{C}$ for $48 \mathrm{~h}$. The supernatants containing non-adherent bacterial cells were discarded. Fresh sterile TSB $(5 \mathrm{~mL})$ was added to the test tubes and re-incubated for $48 \mathrm{~h}$. This procedure was repeated twice. Glass-adherent bacteria created a confluent coat of cells on the sides of the tube. Microorganisms were classified as non-adherent (-: absence of adherence), weakly adherent (+: adherent bacteria appeared as a ring at the interface between the medium and the air), moderately adherent (++: bacteria attached on the side of the 
glass tubes), or strongly adherent (+++: bacteria attached on the side of the glass tubes and at the interface between the medium and the air). S. epidermidis strain ATCC 35984 was used as a positive control (Mattos-Guaraldi and Formiga, 1991).

\section{Multiplex-polimerase chain reaction (PCR) assays}

Twenty E. coli strains were submitted to simple boiling method for DNA extraction, suspended in water injection and maintained at $-20^{\circ} \mathrm{C}$ (Nogueira et al., 2015) in order to search for EHEC, EPEC, STEC, EIEC, EAEC and ETEC, PCR targeting eaeA (917 bp), stx1 (614 bp), stx2 (779 bp), ial (630 bp), Lt (450 bp) and St (160 bp) genes was employed. The amplification was performed using a reaction mixture which contained $20 \mu \mathrm{L}$ containing 1 X PCR buffer (10 mM Tris HCl, pH 8,4; $25 \mathrm{mM} \mathrm{KCl}), 1.5 \mathrm{mM} \mathrm{MgCl} 2,200 \mu \mathrm{M}$ dNTPs (Promega, Madison, WI, USA), $0.5 \mu \mathrm{M}$ of each primer (Integrated DNATechnologies, Coralville, IA, USA), 1 U Taq DNA polimerase (Phoneutria, Belo Horizonte, MG, Brazil), and $2 \mu \mathrm{L}$ of DNA. In each batch of positive reaction, controls were employed. The amplification conditions used were as follows: an initial denaturation step at $95 \circ \mathrm{C}$ for 5 min was performed, followed by 35 cycles of $94 \circ \mathrm{C}$ for $45 \mathrm{~s}$, annealing at $55 \circ \mathrm{C}$ for $1 \mathrm{~min}$ and elongation at $62 \circ \mathrm{C}$ for $2 \mathrm{~min}$. A final elongation step was executed at 72 -C for $5 \mathrm{~min}$. Amplicons were resolved by electrophoresis on SYBR Safe DNA Gel Stain (ThermoFisher Scientific, Vilnius, Lithuania). Gels were evaluated using E-gel Imager, and amplicon sizes were compared with 100 bp DNA ladder (ThermoFisher Scientific, Vilnius, Lithuania) (Chandra et al., 2013).

\section{Bacterial interaction with human colon adenocarcinoma cell line Caco-2 -}

Human colon adenocarcinoma cells Caco-2 were used in adherence, invasion and persistence assays (Pereira et al., 2008). Epithelial cells were grown in 96-well cell culture clusters to confluent monolayers ( $10^{7}$ cells per well) in Minimum Essential Medium Eagle (Sigma-Aldrich) supplemented with 10\% bovine fetal serum. Mid-log-phase bacteria were cultured in Trip Soy Broth - TSB for $24 \mathrm{~h}$ at $37^{\circ} \mathrm{C}$ and reach OD $580 \mathrm{~nm}$ of 0.2 were then added to each well with $\mathrm{MOI}$ of 10 and 100 bacteria per epithelial cell to test the influence of the amount of inoculated bacteria on the number of internalized bacteria. Internalization assays was allowed to occur for $2 \mathrm{~h}$ and $4 \mathrm{~h}$ at $37^{\circ} \mathrm{C}$ in an atmosphere of $94 \%$ air- $6 \% \mathrm{CO} 2$.

To determine the level of bacterial adhesion, 96-well plates containing epithelial cells incubated with mid-log-phase bacteria had been prewashed three times with PBS and lysed with $100 \mathrm{ul} \mathrm{PBS-triton} \mathrm{(Sigma-Aldrich)} \mathrm{to} \mathrm{enumerate} \mathrm{adherent} \mathrm{bacteria} \mathrm{added.} \mathrm{All}$ strains were shown to be susceptible to $\leq 150 \mathrm{mg} / \mathrm{mL}$ of gentamicin to the invasion experiments and were incubated for $1 \mathrm{~h}$ to determine the bacterial invasion. After incubation period, monolayers were washed three times with saline and lysed with $0.1 \%$ Triton X-100 to determine the viable counts of released intracellular bacteria. Invasion ability was expressed as the percentage of inoculum that survived $150 \mathrm{mg}$ of gentamicin per $\mathrm{ml}$ treatment. Following the invasion period as described above, assay of rsistence was demonstrated after $24 \mathrm{~h}$. The infected cells were incubated at $37^{\circ} \mathrm{C}$ in $5 \% \mathrm{CO} 2 \mathrm{using} 150 \mathrm{mg}$ of gentamicin per ml. The results were recorded as percentage of the original inoculum. All assays were conducted in triplicate and were repeated independently at least three times (Hirata Jr. et al., 2004; Sahly et al., 2000).

\section{Results}

In this study, a total of 34 E. coli strains were identified by MALDI-TOF mass spectrometry with $\geq 2$ score. Analysis of data showed that all strains presented resistance to at least one group of antimicrobial agents tested, and expressed a resistant (R) profile. Interestingly, 20 of $34(58.8 \%)$ E. coli river isolates presented resistance to three or more antimicrobial group of interest and were considered as multi-drug resistance (MDR). Multi-drug resistance of $E$. coli river isolates included resistance to $3^{\text {rd }}$ and $4^{\text {th }}$ cephalosporin, aminoglycosides, fluorquinolones and carbapenems (Table 1).

Analysis of biofilm formation ability of resistant and MDR E. coli strains demonstrated that all strains were able to promoted biofilm formation on polyestirene surface in different levels. From the 20 MDR E. coli strains, 40\% $(n=8)$ were considered as strongly adherent on both polyestinere and glass surfaces, followed by $20 \%(n=7)$ moderated adherent, $20 \%(n=4)$ weakly adherent and $5 \%(n=1)$ non-adherent. Resistant $E$. coli also demonstrated heterogeneity among both polyestinere and glass biofilm formation: $42.8 \%(n=6)$ were able to promote biofilm formation and were considered as weakly adherent, followed by, 35.7\% ( $n=5)$ as moderated adherent and $7.2 \%(n=1)$ as strongly adherent, while $14.3 \%(n=2)$ of resistant $E$. coli strains were considered as nonadherent (Table 2). 
Further analysis of virulence pathotypes of MDR E. coli strains were displayed in Table 3 and Figure 1. Data showed that 20\% $(n=4)$ of MDR E. coli river isolates expressed virulence pathotypes: EHEC (Ec31); STEC and EIEC - hybrid (Ec21) and STEC (Ec30 and Ec10) while $80 \%(n=16)$ did not presented any virulence pathotypes analyzed. Evaluation of the presence of virulence genes demonstrated heterogeneity among the isolates. All four strains presented stx 2 gene followed by $s t x 1(n=1), i a L(n=1)$ and eaeA $(\mathrm{n}=1)$. Multiplex-PCR for $L t$, St and aegg genes presented negative results in all opportunities (Figure 2).

The results of the quantitative cell-associated of MDR E. coli river isolates $(n=4)$ harboring virulence patothypes were shown in Table 2. The highest level of adherence to Caco-2 cells was observed with STEC (Ec10 and Ec30) strains presenting stx2 gene: $63.1 \%$ and $45.9 \%$ respectively. EIEC/STEC (Ec21) and EHEC (Ec31) strains expressed lower ability of adherence to human epithelial cell line: $35.4 \%$ and $27.8 \%$ respectively. Viable internalized bacteria were detected at $1 \mathrm{~h}$ post-infection of the monolayers, regardless of the $E$. coli pathotypes but at different levels. The highest percentages of viable intracellular bacteria deduced from Caco-2 cell-associated bacteria were observed for both STEC (Ec10 and Ec30) strains: $3.5 \%$ and $0.1 \%$ respectively. EIEC/STEC (Ec21) and EHEC (Ec31) strains presented lower percentages of viable intracellular bacteria: $0.007 \%$ and $0.01 \%$ respectively. Bacterial persistence following a longer period of incubation (24h) was displayed in Table 2. All four MDR E. coli analyzed strains were able to survive in the presence of Caco-2 cells at different levels: EIEC/STEC (Ec21) 1.8\%; EHEC (Ec31) $3.14 \%$, STEC (Ec30) $18.3 \%$ and STEC (Ec10) 145.8\%. Interestingly, the STEC (Ec10) isolate not only persisted viable but also was capable to multiply within the Caco-2 cell.

\section{Discussion}

E. coli strains are highly affected by the propagation of resistance and virulence genes in urban rivers when compared to other Enterobacteriacea (Tortora, Funke, Case, 2008, Kittinger et al., 2016). However, there is still a poor understanding of the environmental factors that may alleviate the spread of antibiotic resistance. At present, it is not clear to what extent environmental antibiotic resistant bacteria (ARB) and antibiotic resistant genes (ARGs) promote the acquisition and spread of antibiotic resistance among clinically relevant bacteria, or whether ARGs that are acquired by both clinically relevant bacteria and strictly environmental bacteria originate from the same reservoirs (Berendonk, et al., 2015).

In this present study, we documented the presence of resistant and MDR E. coli strains isolated from Joana river, located at Rio de Janeiro metropolitan area, Brazil. Heterogeneity among virulence pathotypes as well as host pathogen interaction with Caco-2 cells was verified among MDR river isolates. The presence of antimicrobial resistant $E$. coli in aquatic systems released from anthropogenic sources such as community, industries, veterinary and hospitals, is a public health concern in industrialized and developing countries due to relevance on environmental dissemination of antimicrobial resistance (Djordjevic, Stokes, Chowdhury, 2013; Berendonk, et al., 2015).

Although generally harmless, E. coli strains may express virulence potential properties that account for human localized and invasive infections in both communities and hospital enviroments (Hall-Stoodley, Costerson, Stoodley, 2004). The plasticity of the E. coli genome has hindered the identification of certain $E$. coli isolates as a pathotype, because some isolates combine the main virulence characteristics of different pathotypes and are thus considered potentially more virulent hybrid pathogenic strains. In this study, MDR E. coli river isolates presented the following distinct pathotypes: STEC, EHEC, EIEC/STEC.

MDR E. coli Ec31 isolated strain was classified as EHEC due to the ability to produces stx 1 and stx2 Shiga toxin (Stx) cytotoxins associated with eaeA gene. MDR E. coli strains Ec21, Ec30 and Ec10 presented stx2 Shiga toxin (Stx) cytotoxins.

The association of Stx cytotoxins, especially $s t \times 2$, with severe diseases has been extensively studied by using endothelial cell lines and their ability to adhere is related to EHEC/STEC pathogenesis (Rivas et al., 2016). In addition, biofilm may act as bacterial protection against adverse environmental conditions, especially in aquatic envionment. A study conducted by Biscola and coworkers (2011) evaluated the capacity of biofilm formation in EHEC/STEC strains isolated from different reservoirs and demonstrated strongly ability to adhere on both glass and polystyrene surfaces. In fact, cell invasion and survival of EHEC/STEC strains in cultured human intestinal epithelial cells has been previously described (Cordeiro et al., 2013) and may be related to biofilm strongly adherence. It should be mentioned that this invasive characteristic has been identified in EHEC/STEC serotypes, responsible for human infections (Mateus-Guimarães et al., 2014; Cordeiro et al., 2013) and isolated from water representing an important vehicles of transmission (Lascowski et al., 2013).

Page 5/14 
Our studies also demonstrated the presence of MDR enteroinvasive E. coli Ec21 strain. EIEC is a causative agent of dysentery in humans, especially in developing countries, due to their ability to invade and penetrate cells by endocytosis, as shown in table 2 . Despite the similarities invasion mechanism and symptoms of the disease, the infectious dose of EIEC appears to be a milder and self-limiting form when compared to Shigella, who leads to an exacerbation of proinflammatory response. ElEC was responsible for several outbreaks, but there are few reports on routes of transmission and distribution of this bacterium in nature, including water and cheese (Marier et al., 1973; Valentini et al., 1992) as well as the direct transmission through person-to-person contact. The isolation of EIEC in Brazil has ranged from 0.5 to 15\%, depending on the population investigated (Moreno et al., 2010; Lozer et al., 2013). Toledo and Trabulsi (1990) investigated the presence of this microorganism in different areas of the city of São Paulo. This bacterium has been found related to children with diarrhea (15.9\%). Studies performed outside the city of São Paulo showed a low prevalence of these bacteria, $0.5-2.5 \%$ (Oliveira et al., 1989).

Few studies have been conducted to investigate pathogenic $E$. coli strains in urban rivers, although pollution of surface waters with these pathogens has been implicated in an increased number of disease outbreaks and consequent deaths (Masters et al., 2011).

In attempt to investigate virulence potential of $E$. coli environmental isolates expressing MDR profiles and virulence genes, were investigated for ability of interaction with Caco-2 human intestinal epithelial cells. All MDR E. coli strains of STEC, EHEC and EIEC/STEC pathotypes were able to adhere to epithelial cells surfaces. MDR E. coli (Ec 10 and Ec30) isolates, classified as STEC pathotypes and presenting st 2 gene, expressed the higher ability of adherence, internalization and persistence within Caco-2 epithelial cells. Previous report documented that STEC annually was responsible to 2,801,000 cases of acute illness, 3890 HUS cases, 270 permanent end-stage renal disease and 270 deaths worldwide and cases of infections have been traced to person-toperson transmission (Duffy, Burgess, Bolton, 2014; Majowicz et al., 2014).

Presently, MDR E. colistrain (EC21) of EIEC pathotypes and harboring ial gene, showed the ability of adherence, internalization and persistence within Caco-2 epithelial cells. EIEC infection occurs via fecal-oral route by the ingestion of contaminated food or water and invasion of colonic epithelium, causing abdominal cramps, bloody and mucous diarrhea. During the last decades, there are an increase number of EIEC cases in varied countries, including two large outbreaks in Europe (Thong et al., 2005; Bueris et al., 2007; Michelacci et al., 2020).

Moreover, one MDR E. coli (Ec31) river isolate was characterized as EHEC, presenting lower levels of adherence, internalization and persistence within Caco-2 epithelial cells. Virulence potential of this pathotypes is partially demonstrated by the ability of attaching intimately and effacing microvilli of epithelial intestinal cells that can directly induce renal and endothelial lesions due to expression of eaeA, Stx 1 and Stx2 genes (Donnenberg, 1993; Maule, 2000; Gomes et al., 2016). Survival and persistence of EHEC in contact with surfaces and exposure to water environments among other conditions should be recognized as important risk factors in the spread of this pathogen, including rivers located at metropolitan areas. Data that deserves attention

In this study, one MDR E. coli (Ec31) river isolate was characterized as EHEC, presenting lower levels of adherence, internalization and persistence within Caco-2 epithelial cells, possibly related to previously described cytotoxicity abilities - whether apoptosis and/or necrosis (Donnenberg, 1993; Maule, 2000; Gomes et al., 2016; Abul-Milh et al., 2001). Data reinforce the fact that survival and persistence of EHEC in contact with surfaces and exposure to water environments among other conditions should be recognized as important risk factors in the spread of this pathogen, including rivers located at metropolitan areas. Information that deserves attention concerning the virulence potential and risk of contamination by EHEC pathotypes is the ability of causing acute infections with only ten bacterial cells indicating a high virulence level (Maule, 2000).

\section{Conclusion}

In conclusion, this study demonstrates the presence of diarrheagenic $E$. coli strains in river water source at Rio de Janeiro metropolitan area, Brazil. However, a subset of these strains demonstrated a high pathogenic potential as they exhibited a multidrug resistant phenotype and virulence genes. The possibility of contamination leading to human infection and cause gastrointestinal disease due to MDR E. coli presenting virulence pathotypes water-borne pathogens is a matter of concern. The presence of diarrheagenic $E$. coli in river waters warrants the implementation of environmental safety strategies in order to avoid 
the dissemination of clones to people leaving in the area but particularly those more vulnerable communities who utilize these waters for domestic purposes, including Rio de Janeiro.

\section{Declarations}

\section{Conflict of interest}

There are no conflicts of interest among the author

\section{References}

1. Abe, C. M.; Salvador, F. A.; Falsetti, I. N.; Vieira, M. A.; Blanco, J.; Blanco, J. E.; et al. Uropathogenic Escherichia coli (UPEC) strains may carry virulence properties of diarrhoeagenic E. coli. FEMS Immunology Medical Microbiology, v. 52, p. 397-406, 2008.

2. Abul-Milh, M.; Wu, Y.; Lau, B.; Lingwood, C. A.; Foster, D. B. Induction of epithelial cell death including apoptosis by enteropathogenic Escherichia coli expressing bundle-forming pili. Infection and Immunity, 2001.

3. Ashbolt, N.J. Microbial contamination of drinking water and disease outcomes in developing regions. Elsevior. 198:3: 229-238; 2004.

4. Bauer, A. W.; Kirby, W. M.; Sherris, J. C.; Turck, M. Antibiotic susceptibility testing by a standardized single disk method. American Journal of Clinical Pathology, v. 45, p. 493-496, 1966.

5. Berendonk, T. U.; Manaia, C. M.; Merlin, C.; Fatta-Kassionos, D.; Cytryn, E.; Walsh, F.; Burgmann, H.; et al. Tackling antibiotic resistance: the environmental framework. Nature Reviews Microbiology, 2015.

6. Beutin, L.; Krause, G.; Zimmermann, S.; Kaulfuss, S.; Gleier, K. Characterization of Shiga Toxin-Producing Escherichia coli Strains Isolated from Human Patients in Germany over a 3-Year Period. Journal of Clinical Microbiology, V. 42, n. 3, p. 10991108, 2004.

7. Biscola F.T.; Abe C.M.; Guth B.E.C. Determination of adhesin gene sequences in, and biofilm formation by, 0157 and non-0157 Shiga toxin-producing Escherichia coli strains isolated from different sources. Applied Environmental Microbiology, v. 77, n. 7, 2011

8. Bueris, V.; Sircili, M. P.; Taddei, C. R.; Santos, M. F.; Franzolin, M. R.; Martinez, M. B.; Ferrer, S. R.; Barreto, M. L.; Trabulsi, L. R. Detection of diarrheagenic Escherichia coli from children with and without diarrhea in Salvador, Bahia, Brazil. Memórias do Instituto Oswaldo Cruz, v. 102, n. 7, p. 839-844, 2007.

9. Brito, B.G.; Vidotto, M.C.; Berbel, M.M.; Tagliari, K.C. Virulence factors of uropathogenic Escherichia coli- UPEC strains for pigs. Ciência Rural. 34:2; 2004.

10. Carbonnelle, E.; Mesquita, C.; Bille, E.; Day, N.; Dauphin, B.; Beretti, J. L.; Ferroni, A.; Gutmann, L.; Nassif, X. Maldi-tof mass spectrometry tools for bacterial identification in clinical microbiology laboratory. Clinical Biochemistry, v.44, 2011.

11. Chandra, M.; Cheng, P.; Rondeau, G.; Porwollik, S.; McClelland, M. A single step multiplex PCR for identification of six diarrheagenic E. coli pathotypes and Salmonella. International Journal of Medical Microbiology, v. 303, p. 210-216, 2013.

12. Cordeiro F., Silva R.I.K., Vargas-Stampe T.L.Z., Cerqueira A.M.F., Andrade J.R.C. Cell invasion and survival of Shiga toxinproducing Escherichia coli within cultured human intestinal epithelial cells. Microbiology, V. 159, p. 1683-1694, 2013

13. CLSI- Clinical Laboratories Standards Institute. Performance Standards for antimicrobial disk susceptibility tests. Approved Standard CLSI Document M2, 2019. Clinical Laboratories Standards Institute, Waine. PA EUA.

14. Djordjevic SP, Stokes HW, Chowdhury PR. Mobile elements, zoonotic pathogens and commensal bacteria: conduits for the delivery of resistance genes into humans, production animals and soil microbiota. Frontiers in Microbiology. 2013;4(86):1-12.

15. Donnenberg, M. S.; Tzipori, S.; McKee, M. L.; O’Brien, A. D.; Alroy, J.; Kaper, J. B. The role of the eae gene of enterohemorrhagic Escherichia coli in intimate attachment in vitro and in a porcine model. The Journal of Clinical Investigation, v. 9, n. 3, p. 14181424, 1993.

16. Duffy, G., Burgess, C. M., Bolton, D. J. A review of factors that affect transmission and survival of verocytotoxigenic Escherichia coli in the European farm to fork beef chain. Meat Science, v. 97, p. 375-383, 2014. 
17. Fleckenstein, J. M.; Kuhlmann, F. M. Enterotoxigenic Escherichia coli Infections. Current Infectious Disease Reports, n. 9, 2019.

18. Gomes, T. A. T.; Elias, W. P.; Scaletsky, I. C. A.; Guth, B. E. C.; Rodrigues, J. F.; Piazza, R. M. F.; Ferreira, L. C. S.; Martinez, M. B. Diarrheagenic Escherichia coli. Brazilian Journal of Microbiology, v. 47, n. 1, p. 3-30, 2016.

19. Gomi, R., Matsuda, T., Fujimori, Y., Harada, H., Matsui, Y. and Yoneda, M. Characterization of pathogenic Escherichia coli in river water by simultaneous detection and sequencing of 14 virulence genes. Environmental Science Technologies, v. 49, p. 6800-6807, 2015.

20. Hall-Stoodley, L.; Costerton, J.W.; Stoodley, P. Bacterial biofilm: from the natural environment to infectious disease. Nature Reviews Microbiology. 2:2: 65-108; 2004.

21. Hirata Jr, R.; Souza, S. M. S.; Rocha-de-Souza, C. M; Andrade, A. F. B.; Monteiro-Leal L. H.; Formiga, L. C. D.; Mattos-Guaraldi, A. L. Patterns of adherence to HEp-2 cells and actin polymerization by toxigenic Corynebacterium diphtheriae strains. Microbial Pathogenesis, v. 36, p. 125-130, 2004.

22. Kalita, A.; Hu, J.; Torres, A. G. Recent advances in adherence and invasion of pathogenic Escherichia coli. Current Opinion in Infectious Diseases, v. 27, n. 5, p. 459-464, 2014.

23. Kittinger, C.; Lipp, M.; Folli, B.; Kirschner, A.; Baumert, R.; Galler, H.; Grisold, A. J.; Luxner, J.; Weissenbacher, M.; Farnleitner, A. H.; Zarfel, G. Enterobacteriaceae Isolated from the River Danube: Antibiotic Resistances, with a Focus on the Presence of ESBL and Carbapenemases. PLoSOne, v. 11, n. 11, 2016.

24. Lascowski K. M. S.; Guth B. E. C.; Martins F. H.; Rocha S. P. D.; Irino K.; Pelayo J. S. Shiga toxin-producing Escherichia coli in drinking water supplies of North Paraná State, Brazil. Journal of Applied Microbiology, v. 114, p. 1230-1239, 2013

25. Leimbach, A.; Hacker, J.; Dobrindt, E. E. coli as na all-rounder: the thin line between commensalism and pathogenicity. Current Topics in Microbiology and Immunology, v. 358, p. 3-32, 2013.

26. Lozer, D. M.; Souza, T. B.; Monfardini, M. V. Genotypic and phenotyoic analysis of diarrheagenic Escherichia coli strains isolated from Brazilian children living in low socioeconomic level communities. BMC Infectious Diseases, v. 13, 2013.

27. Luck, S. N.; Bennett-Wood, V.; Poon, R.; Robins-Browne, R. M.; Hartland, E. L. Invasion of Epithelial Cells by Locus of Enterocyte Effacement-Negative Enterohemorrhagic Escherichia coli. Infection and Immunity, p. 3063-3071, 2015.

28. Magiorakos, A.P.; Srinivasan, A.; Carey, R.B.; Carmeli, Y.; Falagas, M.E. Giske, C.G.; Harbarth, S.; Hindler, J.F.; Kahlmeter, G.; olsson-Liljequist, B.; Paterson, D.L.; Rice, L.B.; Stelling, J.; Struelens, M.J.; Vatopoulos, A.; Weber, J.T.; Monnet, D.L. Multidrugresistant, extensively drug-resistant and pandrug-resistant bacteria: an international expert proposal for interim standard definitions for acquired resistance. Clinical Microbiology and Infection. 2011.

29. Majowicz, S. E., Scallan, E., Jones-Bitton, A., Sargeant, J. M., Stapleton, J., Angulo, F. J., et al. Global incidence of human Shiga toxin-producing Escherichia coli infections and deaths: A systematic review and knowledge synthesis. Foodborne Pathogens and Disease, v. 11, p. 447-455, 2014.

30. Marier R.; Wells J. C.; Swanson R. C.; Callahan W.; MehIman I. J. An outbreak of enteropathogenic E. coli foodborne disease traced to imported cheese. Lancet, v. 302, p. 13-76-1378, 1973.

31. Masters, N.; Wiegand, A.; Ahmed, W.; Katouli, M. Escherichia coli virulence genes profile of surface waters as an indicator of water quality. Water Research, v. 45, n. 19, p. 6321-6333, 2011.

32. Matheus-Guimarães C.; Gonçalves E.; Guth B.E.C. Interactions of 0157 and non-0157 Shiga toxin-producing Escherichia coli (STEC) recovered from bovine hide and carcass with human cells and abiotic surfaces. Foodborne Pathogens Diseases, v. 3 , p. 248-255, 2014.

33. Mattos-Guaraldi, A. L.; Formiga, L. C. Relationship of biotype and source to the hemagglutination and adhesive properties of Corynebacterium diphtheriae. Brazilian Journal of Medical Biology Research, v. 24, p. 399-406, 1991

34. Maule, A. Survival of verocytotoxigenic Escherichia coli 0157 in soil, water and on surfaces. Journal of Applied Microbiology, v. 88, p. 71S-78S, 2000.

35. Michelacci, V.; Tozzoli, R.; Arancia, S.; D’Angelo, A.; Boni, A.; Knijn, A;; Prosseda, G.; et al. Tracking back the evolutionary route of Enteroinvasive Escherichia coli (EIEC) and Shigella through the example of the example of the highly pathogenic 096:H19 EIEC clone. Frontiers in Cellular and Infection Microbiology, v. 10, n. 260, 2020. 
36. Moreno, A. C.; Fernandes-Filho, A.; Gomes, T. A. T. Etiology of childhood diarrhea in the northeast of Brazil: significant emergent diarrheal pathogens. Diagnostic of Microbiological Infectious Diseases, v. 66, p. 50-57, 2010.

37. Nogueira, B. A.; Olivella, J. G. B., Gil, A. C.; Meirelles-Pereira, F.; Gonçalves, V. D.; Andrade, A. F. B.; Bello, A. R.; Pereira, J. A. A. Detection of bacterial samples on the aquatic ecosystems adjacent to Saquarema Lagoon - Rio de Janeiro. Revista de Ciências Médicas e Biológicas. 14:2: 147-152; 2015

38. Oliveira, M. G.; Pessoa, G. V. A.; Nakahara, L. K. Enteropathogenic bactéria occurrence in diarrheic children living in Juiz de Fora municipality Minas Gerais Brazil. Revista do Instituto Adolfo Lutz, v. 49, p. 161-168, 1989.

39. Pereira, A. C. M.; Britto-Filho, J. D.; Carvalho, J. J.; Luna, M. G.; Rosa, A. C. P. Enteroaggregative Escherichia coli (EAEC) strains enter and survive within cultured intestinal epithelial cells. Microbial Pathogenesis, v. 45, p. 310-314, 2008.

40. Rivas M.; Chinen I.; Guth B. E. C. Enterohemorrhagic (Shiga toxin-producing) Escherichia coli. In: Torres A.G., editor. Escherichia coli in the Americas. Springer International Publishing; p. 97-123, 2016.

41. Sahly, H.; Podschun, R.; Oelschlaeger, T. A.; et al. Capsule impedes adhesion to and invasion of epithelial cells by Klebsiella pneumoniae. Infection and Immunity, v. 68, n. 9, 2000.

42. Serapio-Palacios, A.; Finlay, B. B. Dynamics od expression, secretion and translocation of type III effectors during enteropathogenic Escherichia coli infection. Current Opinion in Microbiology, v. 54, 2020.

43. Toledo, M. R. F.; Trabulsi, L. R. Frequency of enteroinvasive Escherichia coli in cildren with diarrhea and healthy controls in São Paulo, SP, Brazil. Revista de Microbiologia, v. 21, 1990.

44. Tortora, G. J.; Funke, B. R.; Case, C. L. Microbiologia. 8 ed. Porto Alegre: Artmed, 2008.

45. Thong, K. L.; Hoe, S. L. L.; Puthucheary, S. D.; Yasin, R. M. D. Detection of virulence genes in Malaysian Shigella species by multiplex PCR assay. BMC Infectious Diseases, v. 5, n. 8, 2005.

46. Valentini S.R., Gomes T.A.T., Falcão D.P. Lack of virulence factors in Escherichia coli strains of enteropathogenic serougroups isolated from water. Applied Environmental Microbiology, v. 58, p. 412-414, 1992.

47. Van Belkum, A.; Tassios, P. T.; Dijkshoorn, L.; Haeggman, S.; Cookson, B.; Fry, N. K.; Fussing, V.; Green, J.; Feil, E.; Gerner-Smidt, P.; Brisse, S.; Struelens, M. Guidelines for the validation and application of typing methods for use in bacterial epidemiology. Clinical Microbiology and Infectious Diseases, v. 13, suppl. 3, p. 1-46, 2007

48. Xiong, W.; Sun, Y.; Zhang, T.; Ding, X.; Li, Y.; Wang, M.; Zeng, Z. Antibiotics, antibiotic resistance genes and bacterial community composition in fresh water aquaculture environment in China. Environmental Microbiology. 2015.

\section{Tables}

Table 1: Resistance profile of E. coli strains isolated at Joana river, located at Rio de Janeiro metropolitan area, Brazil 


\begin{tabular}{|c|c|c|}
\hline $\begin{array}{l}\text { E. } \\
\text { coli strains }\end{array}$ & \multicolumn{2}{|c|}{ Antimicrobial resistance profiles } \\
\hline Ec10 & MDR & CFZ/CFO/CRX/CTX/CRO/CAZ/CPM/GEN/AMI/KAN/TOB/PPT/AMC/ASB/CIP/NOR/IMI/ETP/ATM/SUT \\
\hline Ec31 & MDR & CFL/CTX/ CRO/CAZ/CPM GEN/KAN/TOB/AMP/AMC/ASB/NOR/SUT/TET \\
\hline Ec21 & MDR & CFL/CFZ/CRX/CTX/CRO/GEN/AMI/AMP/AMC/CIP/NOR/SUT/TET \\
\hline Ec30 & MDR & CFL/CFZ/CFO/CRX/CTX/CRO/CAZ/KAN/TOB/ETP/ATM/TET \\
\hline \multirow[t]{2}{*}{ Ec27 } & MDR & CFL/CFZ/CFO/CRX/CTX/CRO/CAZ/CPM/GEN/AMI/KAN/TOB/NOR/ETP/ \\
\hline & & ATM/SUT \\
\hline \multirow[t]{2}{*}{ Ec04 } & MDR & CFL/CFZ/CRX/CTX/CRO/CPM/AMI/KAN/AMP/AMC/ASB/CIP/NOR/IMI/ETP/ \\
\hline & & TET \\
\hline Ec06 & MDR & CFL/CFZ/CFO/CRX/CTX/CRO/CAZ/CPM/AMI/KAN/TOB/AMP/IMI/ETP/ATM/SUT \\
\hline \multirow[t]{2}{*}{ Ec03 } & MDR & CFL/CFZ/CRX/CTX/CRO/CAZ/CPM/AMI/KAN/AMP/NOR/IMI/ETP/ATM/ \\
\hline & & CLO \\
\hline Ec23 & MDR & CFL/CFZ/CRX/CTX/CRO/GEN/AMP/PPT/AMC/ASB/CIP/NOR/SUT/TET \\
\hline Ec32 & MDR & CFL/CFZ/CFO/CRX/CTX/CRO/CAZ/CPM/GEN/KAN/TOB/ETP/ATM \\
\hline Ec33 & MDR & CFL/CFZ/CTX/GEN/AMI/TOB/AMP/AMC/ASB/CIP/NOR/TET \\
\hline Ec34 & MDR & CFL/CFZ/CTX/GEN/AMI/TOB/AMP/AMC/ASB/CIP/NOR/TET \\
\hline Ec01 & MDR & CFL/CFZ/CRX/CTX/AMI/ CIP/NOR/IMI/ETP AMP/ATM/TET \\
\hline Ec22 & MDR & CFZ/CRX/CTX/GEN/KAN/TOB/AMP/CIP/NOR/SUT/TET \\
\hline Ec16 & MDR & CFL/CRX/CTX/GEN/AMI/TOB/AMP/AMC/SUT/TET \\
\hline Ec15 & MDR & CFL/CFZ/CRX/CRO/CPM/CIP/NOR/IMI/TET \\
\hline Ec24 & MDR & CRX/CTX/GEN/AMI/AMP/NOR/SUT/TET \\
\hline Ec29 & MDR & GEN/TOB//ETP/AMP/ASB/NOR/SUT/TET \\
\hline Ec08 & MDR & CFL/CFZ/CRX/CTX/GEN/AMP/NOR/TET \\
\hline Ec18 & MDR & CFL/CFZ/CFO/CRX/CAZ/KAN/TOB/ETP \\
\hline Ec13 & $\mathrm{R}$ & CFL/CFZ/CFO/CTX/CRO/CAZ/AMP/PPT/AMC/CIP/TET \\
\hline Ec05 & $\mathrm{R}$ & CFL/CFZ/CRX/CTX/CRO/CPM/AMP/IMI/ATM/SUT \\
\hline Ec20 & $\mathrm{R}$ & CFL/CFZ/CFO/CTX/GEN/AMI/TOB/AMP/SUT/TET \\
\hline Ec19 & $\mathrm{R}$ & CFZ/CTX/GEN/AMI/AMP/ASB/SUT/TET \\
\hline Ec02 & $\mathrm{R}$ & CFL/CFZ/CRX/CTX/CRO/AMP/IMI/SUT \\
\hline Ec17 & $\mathrm{R}$ & CFL/CFZ/CTX/GEN/AMP/SUT/TET \\
\hline Ec07 & $\mathrm{R}$ & CFL/CFZ/CRX/CTX/GEN/AMP \\
\hline Ec26 & $\mathrm{R}$ & GEN/AMP/AMC/SUT/TET \\
\hline Ec11 & $\mathrm{R}$ & CFL/CFZ/CRX/AMP/SUT \\
\hline Ec12 & $\mathrm{R}$ & CFL/CFZ/CRX/CRO/AMP \\
\hline Ec25 & $\mathrm{R}$ & CTX/GEN/AMP/SUT/TET \\
\hline Ec28 & $\mathrm{R}$ & CTX/GEN/AMP/SUT/TET \\
\hline
\end{tabular}




\begin{tabular}{|lll|}
\hline Ec09 & $\mathrm{R}$ & $\mathrm{CFL} / \mathrm{CFZ} / \mathrm{AMP} / \mathrm{AMC}$ \\
$\mathrm{Ec14}$ & $\mathrm{R}$ & $\mathrm{CFL} / \mathrm{CFZ} / \mathrm{CRX} / \mathrm{AMP}$ \\
\hline
\end{tabular}

Legend: R- resistant, MDR-multi-drug resistant; CFL-cephalothin, CFZ-cefazolin, CFO-cefoxitin, CRX-cefuroxime, CTX-cefotaxime, CRO-ceftriaxone, CAZ-ceftazidime, CPM-cefepime, GEN-gentamicin, AMI-amikacin, KAN-kanamycin, TOB-tobramycin, AMPampicillin, PPT-piperacillin/taxobactam, AMC-amoxicillin/clavulanic acid, ASB-ampicillin/sulbactam, CIP-ciprofloxacin, NORnorfloxacin, IMI-imipenem, ETP-ertapenem, MER-meropenem, ATM-aztreonam, CLO-chloramphenicol, TET-tetracycline, SUTcotrimoxazole, COL-colistin

Table 2: Biofilm formation ability of E. coli strains isolated at Joana river, located at Rio de Janeiro metropolitan area, Brazil 


\begin{tabular}{|c|c|c|}
\hline \multirow{2}{*}{$\begin{array}{l}\text { E. coli } \\
\text { strain }\end{array}$} & \multicolumn{2}{|l|}{ Biofilm formation } \\
\hline & Polystyrene Surface & Glass surface \\
\hline Ec10 & SA & +++ \\
\hline Ec31 & SA & +++ \\
\hline Ec21 & SA & +++ \\
\hline Ec30 & SA & +++ \\
\hline Ec27 & MA & ++ \\
\hline Ec04 & WA & + \\
\hline Ec06 & MA & ++ \\
\hline Ec03 & WA & + \\
\hline Ec23 & MA & ++ \\
\hline Ec32 & MA & ++ \\
\hline Ec33 & MA & ++ \\
\hline Ec34 & MA & ++ \\
\hline Ec01 & MA & ++ \\
\hline Ec22 & SA & +++ \\
\hline Ec16 & WA & + \\
\hline Ec15 & SA & +++ \\
\hline Ec24 & NA & - \\
\hline Ec29 & SA & +++ \\
\hline Ec08 & SA & +++ \\
\hline Ec18 & WA & + \\
\hline Ec13 & MA & ++ \\
\hline Ec05 & WA & + \\
\hline Ec20 & MA & ++ \\
\hline Ec19 & SA & +++ \\
\hline Ec02 & MA & ++ \\
\hline Ec17 & WA & + \\
\hline Ec07 & WA & + \\
\hline Ec26 & MA & ++ \\
\hline Ec11 & WA & + \\
\hline Ec12 & WA & + \\
\hline Ec25 & WA & + \\
\hline Ec28 & NA & - \\
\hline Ec09 & MA & ++ \\
\hline Ec14 & NA & - \\
\hline
\end{tabular}

Page 12/14 
Legend: SA/ +++: strongly adherent, MA/++: moderated adherent; +: adherent bacteria appeared as a ring at the interface between the medium and the air.

Table 3: Virulence genes, pathotypes and cell interaction results of MDR Escherichia coli isolated from river environment located at Rio de Janeiro metropolitan area, Brazil.

\begin{tabular}{|c|c|c|c|c|c|c|}
\hline \multirow[t]{2}{*}{ Strains } & \multirow[t]{2}{*}{ Virulence genes } & \multirow[t]{2}{*}{ Pathotypes } & \multicolumn{4}{|c|}{ Caco-2 epithelial cells } \\
\hline & & & Control & Adherence & Internalazied bacteria $(1 \mathrm{~h})$ & Persistance (24h) \\
\hline EC31 & Stx1, stx2, eaeA & EHEC & $6.1 \times 10^{8}$ & $1.7 \times 10^{8}(27.8 \%)$ & $2.1 \times 10^{4}(0.01 \%)$ & $6.6 \times 10^{2}(3.14 \%)$ \\
\hline EC21 & Stx2, iaL & EIEC; STEC & $4.8 \times 10^{8}$ & $1.7 \times 10^{8}(35.4 \%)$ & $1.2 \times 10^{4}(0.007 \%)$ & $2.2 \times 10^{2}(1.8 \%)$ \\
\hline \multirow[t]{2}{*}{ EC30 } & Stx2 & STEC & $3.7 \times 10^{8}$ & $1.7 \times 10^{8}(45.9 \%)$ & $6 \times 10^{4}$ & 1.1.x $10^{3}(18.3 \%)$ \\
\hline & & & & & $(3.5 \%)$ & \\
\hline EC10 & Stx2 & STEC & $3.8 \times 10^{8}$ & $2.4 \times 10^{8}(63.1 \%)$ & $2.4 \times 10^{5}(0.1 \%)$ & $3.5 \times 10^{5}(145.8 \%)$ \\
\hline
\end{tabular}

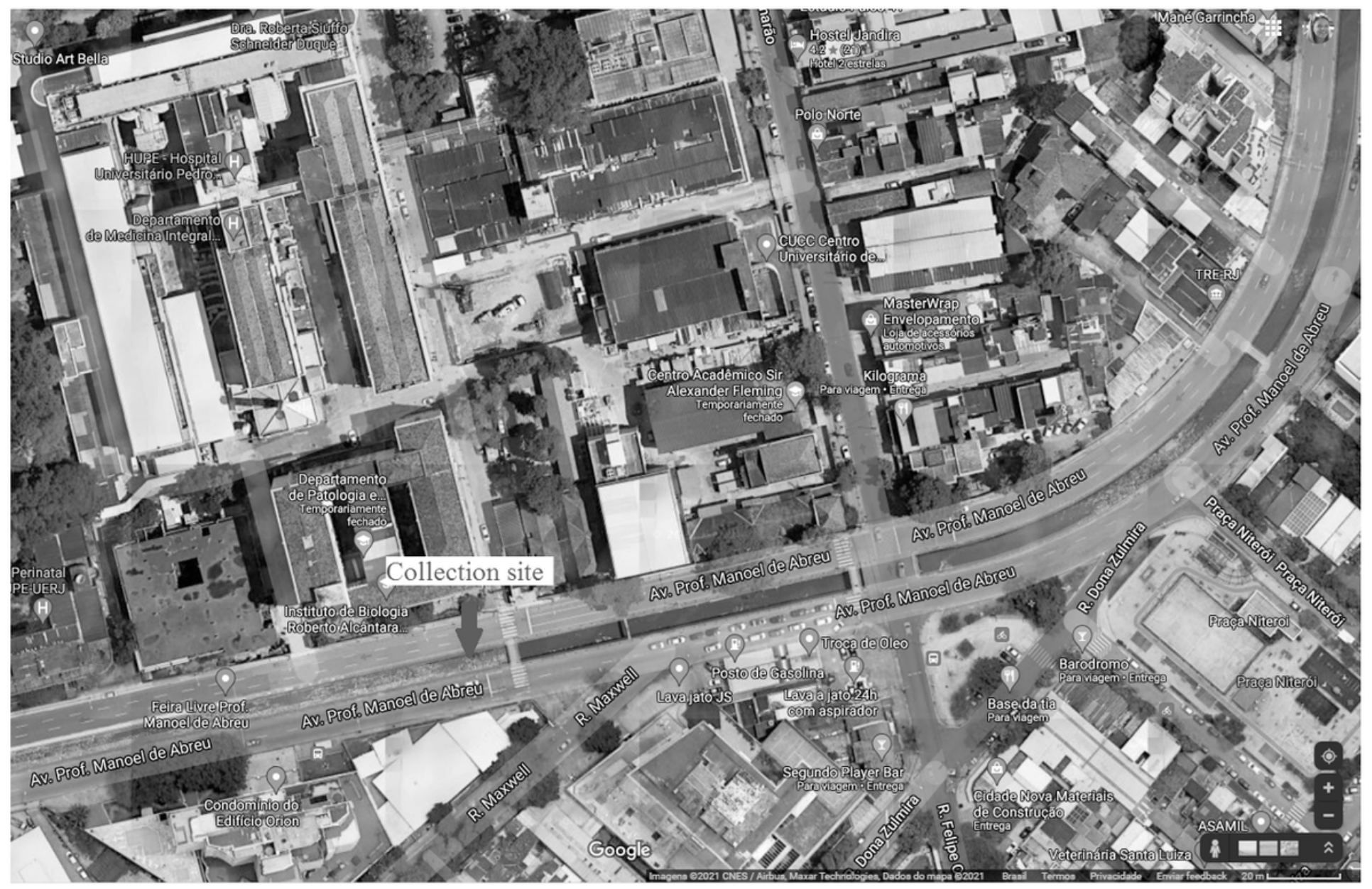

Figure 1

Collection site of water samples from Joana River located in front of a University Hospital at Rio de Janeiro metropolitan area, Southeast Brazil 


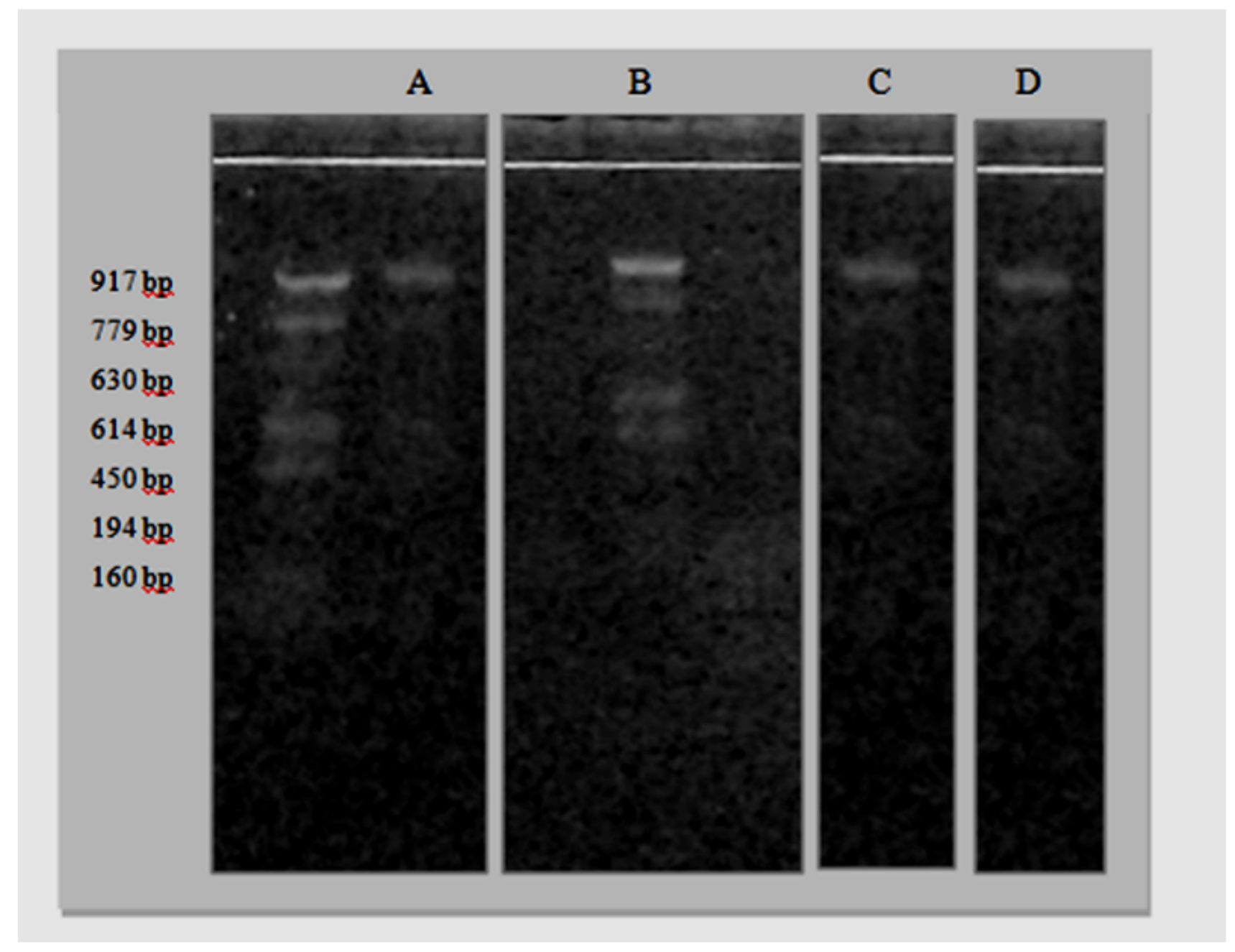

\section{Figure 2}

Amplification profile scheme generated by MPCR for multidrug-resistant Escherichia coli and determination of virulence genes: eaeA (917 bp), stx1 (614 bp), stx2 (779 bp), iaL (630 bp), Lt (450 bp) and St (160 bp) corresponding to A- STEC and EIEC (Ec21); BEHEC (Ec31) and C and D-STEC (Ec30 and Ec10) strains. 